\title{
Evaluation of determinants of the serological response to the split-inactivated influenza vaccine
}

Shaohuan Wu1 , Ted M. Ross ${ }^{2,3}$, Michael A. Carlock ${ }^{2,3}$, Elodie Ghedin ${ }^{1,4}$, Hyungwon Choi $^{5}$, Christine Vogel ${ }^{1^{*}}$

${ }^{1}$ Center for Genomics and Systems Biology, New York University, New York, USA;

${ }^{2}$ College of Veterinary Medicine, Department of Infectious Diseases, University of Georgia, Athens, Georgia, USA;

${ }^{3}$ Center for Vaccines and Immunology, University of Georgia, Athens, Georgia, USA;

${ }^{4}$ Systems Genomics Section, Laboratory of Parasitic Diseases, NIAID, NIH, Bethesda, MD, USA;

${ }^{5}$ Department of Medicine, Yong Loo Lin School of Medicine, National University of Singapore, Singapore, Singapore

* Corresponding author: cvogel@nyu.edu 
medRxiv preprint doi: https://doi.org/10.1101/2021.10.07.21264416; this version posted October 11, 2021. The copyright holder for this preprint

(which was not certified by peer review) is the author/funder, who has granted medRxiv a license to display the preprint in perpetuity.

It is made available under a CC-BY-NC-ND 4.0 International license.

\section{Abstract}

The seasonal influenza vaccine is only effective in half of the vaccinated population. To identify determinants of vaccine efficacy, we used data from $>1,300$ vaccination events to predict the response to vaccination measured as seroconversion as well as hemagglutination inhibition (HAI) levels one year after. We evaluated the predictive capabilities of age, body mass index (BMI), sex, race, comorbidities, prevaccination history, and baseline HAl titers, as well as vaccination month and vaccine dose in multiple linear regression models. The models predicted the categorical response for $>75 \%$ of the cases in all subsets with one exception. Prior vaccination, baseline titer level, and age were the strongest determinants on seroconversion, all of which had negative effects. Further, we identified a gender effect in older participants, and an effect of vaccination month. BMI played a surprisingly small role, likely due to its correlation with age. Comorbidities, vaccine dose, and race had negligible effects. Our models can generate a new seroconversion score that is corrected for the impact of these factors which can facilitate future biomarker identification. 
medRxiv preprint doi: https://doi.org/10.1101/2021.10.07.21264416; this version posted October 11, 2021. The copyright holder for this preprint (which was not certified by peer review) is the author/funder, who has granted medRxiv a license to display the preprint in perpetuity. It is made available under a CC-BY-NC-ND 4.0 International license .

\section{Introduction}

Influenza virus infections represent a continuous threat to public health, as vaccine effectiveness is typically low, ranging from $19 \%$ to $60 \%$ during the 2009 to 2018 seasons in the United States, according to the Center for Disease Control (https://www.cdc.gov/flu). The widely used split-inactivated influenza vaccine is typically quadrivalent with an antigen for all four virus subtypes, H1N1 and H3N2 (Influenza A) subtypes, and Yamagata and Victoria lineages (Influenza B). Understanding predictors of vaccine efficacy is an ongoing public health challenge.

While antigenic drift and shift caused by frequent mutations in circulating viral strains are long-known influencers of vaccine efficacy, there is increasing recognition of other factors intrinsic to the human host which impact vaccine efficacy and/or severity of an influenza infection. These factors can be genetic (Orrù et al, 2013; Brodin et al, 2015; Franco et al, 2013), epigenetic (Zimmermann et al, 2016), or represent pre-existing immunity (Henn et al, 2013; HIPC-CHI Signatures Project Team \& HIPC-I Consortium, 2017; Voth et al, 1966; Beyer et al, 1996) as caused by prior infection or vaccination (Sung et al, 2021; Gouma et al, 2020; Zost et al, 2017). Further, demographic factors such as age (Henry et al, 2019; Henry et al, 2019; Goodwin et al, 2006), obesity (Honce \& Schultz-Cherry, 2019; Honce et al, 2020), and sex (Klein \& Flanagan, 2016; Fink et al, 2018; Voigt et al, 2019) are thought to play a role. In addition, recent studies have shown that vaccination time during a flu season can also affect the response to the vaccine (Penkert et al, 2021). However, many of these factors are intercorrelated, e.g. prior vaccination and baseline antibody titer level as well as age, obesity, and other comorbidities. In addition, most existing studies examined the effect of one or a few of these factors (Penkert et al, 2021; Sung et al, 2021; Gouma et al, 2020; Goodwin et al, 2006) without comprehensive integration.

Here, we addressed this gap in knowledge by using a large cohort dataset to construct multiple linear regression models that predicted the response to the split-inactivated influenza vaccine based on nine variables known for participants. We performed the prediction separately for three different age groups, as well as for seroconversion after 3-4 weeks and antibody titer levels in the subsequent year. We evaluated the impact of each individual factor while controlling for the effects of the remaining factors.

\section{Results}

\section{Mining a large cohort study with $>1,300$ vaccination events}

To construct the models, we used one of the largest cohort studies available, involving 700 participants monitored over five flu seasons (cohorts), producing 1,368 vaccination events (Figure 1). We predicted both seroconversion (Seroconversion), measured as the $\log _{2}$ ratio between $\mathrm{HAl}$ (hemagglutination inhibition) titer levels against the four vaccine strains 3 or 4 weeks post vaccination (D21 or D28, respectively) and HAI titer at D0, and the baseline (BL, D0) HAl titer levels in the subsequent year (BaselineSY). In addition to demographic factors, such as age, body mass index (BMI), sex, race, comorbidities, and prevaccination history of participants, we included month of vaccination (September to February), and vaccine dose (for participants $>=65$ years old) to predict Seroconversion and BaselineSY. Based on the longevity of the vaccine's effect (Supplementary Figure S1), we defined participants as prevaccinated if they had received the vaccine in the previous year, and as naive if they had had no vaccine within the last three years, removing cases with a mixed status. We also used HAI levels at D0 or D28 for prediction of Seroconversion and BaselineSY, respectively.

We separated participants into three subpopulations: Children (12-17 years), Adult1 (18-64 years), and Adult2 (>=65 years). Figure 1 shows the distributions of variables across these three groups. Most participants across all groups were prevaccinated which is a substantial determinant of the baseline HAI 
medRxiv preprint doi: https://doi.org/10.1101/2021.10.07.21264416; this version posted October 11 , 2021. The copyright holder for this preprint (which was not certified by peer review) is the author/funder, who has granted medRxiv a license to display the preprint in perpetuity.

It is made available under a CC-BY-NC-ND 4.0 International license .

levels (Figure 2). However, despite prior vaccination, the average baseline HAl level was much lower in the Adult2 group compared to the other two groups: $<25 \%$ of Adult2 participants were seropositive at D0, the beginning of the respective study (Figure 1). Notably, the three subpopulations exhibited a similar seroconversion after the vaccination, indicating that other factors were in play besides baseline level (Figure 1).

Other variables showed different distributions across three subpopulations, which, in part, impacted their ability to predict the outcome of the vaccination. As expected, Adult1 and Adult2 had on average higher BMls than Children, and most Adult2 participants had one or more comorbidities (Figure 1). The three subpopulations were similar with respect to distributions of the remaining demographic factors, i.e. gender and race (Figure 1). Only Adult2 participants had been offered the high dose of the vaccine (Figure 1). Finally, Children and Adult2 participants had primarily been vaccinated in the first three months of a flu season while Adult1 participants were vaccinated evenly throughout the season (Figure 1). For that reason, dose and vaccination month were only useful predictors in the Adult2 and Adult1 subpopulations, respectively (see below).

\section{Predicting over three quarters of the vaccine response}

We predicted Seroconversion and BaselineSY for both the four vaccine strains individually and the composite value calculated as the sum of the values across four strains (Figure 3). For the prediction of Seroconversion, we trained the models on four UGA cohorts and evaluated the prediction on the fifth, independent cohort. For the prediction of BaselineSY, we trained the models on three of the four newly assembled 'BL cohorts' (Methods) and evaluated the prediction on a fourth, independent BL cohort (Figure 3).

First, we evaluated the models with respect to prediction of categories (high vs. low/no Seroconversion; seropositive vs. negative BaselineSY) (Figure 4). All three subpopulations predicted Seroconversion and BaselineSY accurately at $74 \%$ or more in independent test sets. The models performed best for the subsequent year's baseline HAl levels for Adult2 subpopulation (>=65 years old) ( $94 \%$ correct predictions). The models performed worst for prediction of Seroconversion and BaselineSY for the Adult1 subpopulation (18-64 years old), indicating that for these participants, additional factors, e.g., specific comorbidities, impacted the response to vaccination. Supplementary Figure S3 shows the results when evaluating the models across the entire dataset.

\section{Identifying major predictors of Seroconversion and BaselineSY}

Next, we estimated the relative importance of each variable in predicting Seroconversion and BaselineSY for both composite scores (Figure 5) and individual strains (Figure 6). Importantly, our results show the independent effect of each variable, even though several variables are intercorrelated (Supplementary Figure S2). Supplementary Tables $\mathbf{S 1}$ and S2 contain the original data for plotting Figures $\mathbf{5}$ and $\mathbf{6}$, respectively.

As expected, prior vaccination and high HAl baseline levels predicted low Seroconversion and they explain the large majority of variation in each subpopulation. One exception was baseline HAI levels against the H3N2 strain in the Adult2 subpopulation, in which the impact was negligible. Conversely, HAl titer levels at Day 21 or 28, but not prevaccination history, predicted most of the baseline titer level in the subsequent year (BaselineSY). The exception was Children in which prior vaccination had a small positive impact on the vaccine longevity.

Unexpectedly, older participants amongst the Children subpopulation also had lower Seroconversion than younger participants, similar to that among the Adult1 subpopulation, which was largely driven by the effect 
medRxiv preprint doi: https://doi.org/10.1101/2021.10.07.21264416; this version posted October 11, 2021. The copyright holder for this preprint (which was not certified by peer review) is the author/funder, who has granted medRxiv a license to display the preprint in perpetuity. It is made available under a CC-BY-NC-ND 4.0 International license .

of the H1N1 strain. This negative relationship was weak, but significant, as illustrated in Figure 7 which depicts the relationship between the variable and the predicted value removing the effects of all other variables. This relationship suggests that immunosenescence contributable to natural influenza infections starts before adulthood. In comparison, participant age did not predict longevity of the antibodies which (as mentioned above) was almost exclusively determined by HAl titer levels.

Another major predictor was the month of vaccination: the later children and adults $<65$ years received the vaccine in a flu season, the higher Seroconversion was (Figures $\mathbf{5}$ and 7). For the Adult1 subpopulation, this positive effect might have been mostly driven by the effect of the IBV Yamagata strain (Figure 6). The model could not evaluate this variable for the Adult2 subpopulation due to the above-mentioned bias

(Figure 1). The result is consistent with a recent finding (Penkert et al., 2021) and thought to link to natural influenza infections that occur more frequently later in the season, which could cause false positives if they occur during or shortly after the vaccination.

Surprisingly, body mass index had only a minor influence on composite vaccine efficacy: only in the Adult1 subpopulation, BMI had a slightly positive effect on vaccine efficacy (Figure 5 and $\mathbf{7}$ ). When examining the influence of BMI on individual strains, BMI had a positive impact on the response to the H3N2 component in the Adult2 subpopulation. BMI had no impact on vaccine longevity. These results appear to be in contrast to the known negative impact of obesity on influenza severity (Honce \& Schultz-Cherry, 2019; Honce et al, 2020). We speculate that, since BMl and age are positively correlated (Figure 2), the strong age effect masks the effect of BMI on Seroconversion.

Further, we found that women had a higher response than men in the Adult2 subpopulation, largely driven by the IBV Victoria strain (Figures 5 and 6). Race and comorbidities had no or only marginal effects on both Seroconversion and BaselineSY. The surprising lack of impact of comorbidities might be due to its intercorrelation with age (Figure S2), and the fact that comorbidities had only been noted as existing or not (i.e. present/absent) which provided little resolution of specific illnesses. Similarly, use of the high dose vaccine over the standard dose in the Adult2 subpopulation had very little effect on vaccine efficacy.

\section{Discussion}

We systematically examined the effects of nine factors on Seroconversion, i.e. the response to the vaccine 3-4 weeks after vaccination, and BaselineSY, i.e. the HAI titer levels in the subsequent year. To do so, we used a large cohort study with $>1,300$ vaccination events. We predicted Seroconversion and BaselineSY across three subpopulations based on participant age with an overall high accuracy: we predicted categorical classifications correctly in $>3 / 4$ of the cases and numerical values for $>1 / 3$ of the cases across most subpopulations (Figure 4).

Further, the models evaluated the contributions of the variables to the prediction of Seroconversion and BaselineSY (Figures $\mathbf{5}$ and $\mathbf{6}$ ). Across all age groups, the primary factors were vaccination status and baseline titer levels, followed by age and month of vaccination. These findings underscore the importance of pre-existing immunity, i.e. high baseline HAl titer levels against respective strains and longevity of the antibodies formed during prior infections or vaccinations. The impact of pre-existing immunity is an emerging concept (Boyd \& Jackson, 2015; Boyd \& Jackson, 2015; HIPC-CHI Signatures Project Team \& HIPC-I Consortium, 2017; Gonzalez-Dias et al, 2020; Kotliarov et al, 2020; Tsang et al, 2020).

Importantly, we found that in all three subpopulations, prior vaccination and baseline titer levels had both shared and variable-specific contributions to Seroconversion (Figures 2 and 5). In adults, prior vaccination and/or baseline titer levels explained the large majority (if not all) of Seroconversion; the effect was smaller in Children perhaps due to a still maturing immune system. Further, the effect of prior vaccinations was 
medRxiv preprint doi: https://doi.org/10.1101/2021.10.07.21264416; this version posted October 11, 2021. The copyright holder for this preprint (which was not certified by peer review) is the author/funder, who has granted medRxiv a license to display the preprint in perpetuity. It is made available under a CC-BY-NC-ND 4.0 International license .

visible for at least three years post vaccination (Supplementary Figure S1), indicating that antibody longevity is essential to consider when evaluating the vaccine response.

Similar approaches that corrected for baseline titer levels, such as producing a new score called adjMFC, have been very successful in identifying novel transcript markers of the vaccine response (Tsang et al, 2020; HIPC-CHI Signatures Project Team \& HIPC-I Consortium, 2017). However, in contrast to adjMFC, our models included not only baseline titer levels, but a total of nine confounding variables. To our knowledge, our analysis is therefore the most comprehensive of its kind with respect to cohort size and number of variables modeled simultaneously, resulting in robust control of confounding effects and estimation of the effect size.

Our results are validated by previous findings. For example, two studies on small cohorts confirm the negative effect of prior vaccination on Seroconversion (Sung et al, 2021; Gouma et al, 2020). Further, a cross-cohort analysis confirms the negative effect of age on Seroconversion and seroprotection, i.e. the actual titer levels (Goodwin et al, 2006). While this analysis included data from 31 different cohort studies, it suffered from a less accurate estimation of the effect size of age, as several continuous variables had been treated as categorical. Further, our models show that participant sex affects Seroconversion in the Adult 2 subpopulation, consistent with previous findings (Klein \& Flanagan, 2016; Fink et al, 2018; Voigt et al, 2019). However, all of these prior studies examined only a single factor in its effect, therefore ignoring the contribution of other factors.

In comparison to the strong negative effect of age on Seroconversion in the Children and Adult1 subpopulations, (Figure 5 and 7), age was not a predictor of the vaccine response amongst adults older than 65 years (Adult2), contradicting findings on increased flu severity amongst the eldery due to immunosenescence (Huang et al, 2019; Gounder \& Boon, 2019). However, this result is not a contradiction but an extension of these previous findings: we showed that, indeed, participants older than 65 years have lower Seroconversion (Figure 1), but within this age group, age does not have any additional effect (Figure 7). The result indicates that the effect of immunosenescence perhaps reaches saturation beyond a specific age. Further, participants older than 65 years had the choice to receive the high-dose vaccine. However, in contrast to a previous study (DiazGranados et al, 2013), we did not find a positive effect of the high-dose vaccine (Figure 5).

Consistent with a recent finding examining the effect of time of vaccination on immune response (Penkert et al, 2021), we found that Seroconversion was higher when the vaccine was administered later in the season for Children and Adult1 subpopulations. As most participants in the Adult2 subpopulation received the vaccine in September or October of the season, we could not evaluate the effect of vaccination time in this group.

Our results also contribute to the discussion on the role of obesity in infection and vaccination. While obesity is a strong predictor of flu severity (Honce \& Schultz-Cherry, 2019; Honce et al, 2020), conflicting findings exist on its effect on the response to vaccination. In response to an inactivated trivalent influenza vaccine, obese individuals have higher seroconversion than normal weight individuals, but their antibodies are shorter lived (Sheridan et al, 2012). In contrast, other studies found obesity to impact seroconversion negatively in both young and old individuals (Frasca et al, 2016), or to have no influence on the response in the elderly or in children (Talbot et al, 2012; Callahan et al, 2014).

We hypothesize that these inconsistencies may arise from possible shortcomings in using BMI as a measure of metabolic health (Nuttall, 2015), as well as the mixed effect of confounding factors, primarily age. In light of these complex relationships, we interpret our results as follows: In Children, BMI varies relatively little (Figure 1) and is slightly positively correlated with age (Figure 2). The absence of a BMI effect might therefore be due to the predominant effects of prior vaccination, baseline titers and age (Figure 5). In Adult2, BMI is not correlated with age (Figure 2); however, titer levels and seroconversion are generally lower than in the other subpopulation (Figure 1). Similar to our interpretation of a saturation of an 
medRxiv preprint doi: https://doi.org/10.1101/2021.10.07.21264416; this version posted October 11, 2021. The copyright holder for this preprint (which was not certified by peer review) is the author/funder, who has granted medRxiv a license to display the preprint in perpetuity.

It is made available under a CC-BY-NC-ND 4.0 International license .

age effect, we argue that in adults older than 65 years, there is no additional impact of BMI on seroconversion. In comparison, the small and positive contribution of BMI to Seroconversion in the Adult1 subpopulation (Figure 5) can be explained by the clear negative age effect (Figure 5) as well as a substantial correlation between age and BMI (Figure 2). In other words: as age, in addition to prior vaccination and baseline titer levels, accounts for much of the variation in Seroconversion amongst Adult 1 participants, the additional contribution of BMI is only minor.

Our results illustrate the complexity of the effects of multiple factors on the response to vaccination, their non-linear effects and interactions with each other which renders prediction of vaccine efficacy to be a continuing challenge. While our work presents a comprehensive analysis of the factors affecting seroconversion, many additional variables exist that might affect the outcome. For example, genetic makeup, pregnancy, and even the microbiome are shown to affect severity of a flu infection (Kenney et al, 2017; Ghedin \& Schultz-Cherry, 2017; Borges et al, 2018), and might have to be considered in future cohort studies.

The results of our study present an opportunity to complement our ability to identify novel markers of the vaccine response: the residual of the observed and predicted Seroconversion discussed here can serve as a new score, i.e. a Corrected Seroconversion score, which simultaneously accounts for a number of known factors that are typically thought to confound the response to vaccination, such as prevaccination status, age, BMI, sex, or month of vaccination. Using the Corrected Seroconversion would allow identifying markers of the vaccine response independent of what can be explained by the participant's specific background. This would, therefore, serve to complement the "standard" screening using the uncorrected Seroconversion to discover new factors impacting the response to a vaccine.

\section{Methods}

\section{Data pre-processing}

As part of an ongoing study by the University of Georgia, Athens (UGA), a total of 690 participants had been recruited during five seasons between 2016 and 2020 (UGA1-5). Participants received the split-inactivated influenza vaccine Fluzone by Sanofi Pasteur and provided blood samples on the day of vaccination (Day 0 ) (sample collected before the vaccination event) and 21/28 days post vaccination (Day 21/28). Hemagglutination inhibition assays were performed on the blood samples against each of the vaccine strains (Figure 1). Demographic data including age, body mass index (BMI), sex, race, comorbidities, prevaccination history, as well as month of vaccination in a flu season, vaccine dose, and baseline D0 HAI titer levels or post vaccination D21/28 titer levels were used for Seroconversion and BaselineSY predictions.

We used Seroconversion as $\log _{2}$-transformed ratio of HAl titer levels at day $21 / 28$ (D21/28) and day 0 (D0) for each strain, and a composite Seroconversion as the sum of $\log _{2}$-transformed ratios across the strains, as proposed in a previous study (Abreu et al, 2020). We also $\log _{2}$-transformed age and BMI to account for their potential non-linear impact. We removed data points in which the participant had a "mixed" prevaccination status, i.e. had been vaccinated two or three years prior to the vaccination (Supplementary Figure S1). The remaining participants were either naive (vaccinated $>3$ years ago) or prevaccinated (vaccinated 1 year ago). To predict Seroconversion, we used the $\log _{2}$-transformed baseline D0 HAI titer levels, age, BMI, as well as the other demographic factors (variables). To predict BaselineSY, we used the same variables, except that the $\log _{2}$-transformed D0 HAI titer is replaced with $\log _{2}$-transformed D21/28 HAI titer (Figure 3). We had a total of 1,368 vaccination events across five UGA cohorts for Seroconversion prediction, and 672 ones across four newly assembled cohorts (repeated participants between neighboring UGA cohorts, i.e., between 1 and 2, 2 and 3, 3 and 4, and 4 and 5, respectively. They are called Baseline cohorts 1-4) for BaselineSY prediction. 
medRxiv preprint doi: https://doi.org/10.1101/2021.10.07.21264416; this version posted October 11, 2021. The copyright holder for this preprint (which was not certified by peer review) is the author/funder, who has granted medRxiv a license to display the preprint in perpetuity.

It is made available under a CC-BY-NC-ND 4.0 International license.

We performed the prediction in three subpopulations separately: Children (<18 years), Adult1 (18-64 years), and Adult2 ( $>=65$ years). We performed this split based on what is common in this field and on the fact that the high dose version of the vaccine is offered as an option to adults $>=65$ years only - so the effect of dose can only be modeled among Adult2 participants.

\section{Predictive modeling and evaluation with an independent cohort}

We first split the dataset into training and test sets. For Seroconversion prediction, we used UGA cohorts $1-3$ and 5 as the training set and cohort 4 as the test set, as cohort 5 is a relatively biased dataset. Similarly, we used Baseline cohorts 1-2 and 4 as the training set and cohort 3 as the test set.

We then tested different machine learning algorithms in WEKA environment (Ivanciuc, 2008) (https://sourceforge.net/projects/weka/), including Random Forest and Neural Network, and selected multiple linear regression (MLR) as it had the best performance (the largest $R^{2}$ for the test set). So we applied MLR to model the effect of each variable and to predict Seroconversion and BaselineSY, for individual strains as well as the composite score. To reduce redundant variables and avoid potential overfitting, we first did feature selection on the training set. We used WrapperSubsetEval attribute evaluator with the internal classifier set to be LinearRegression, and BestFirst search method, as well as a 10-fold cross-validation setting to do feature selection. Variables that were selected $>=1$ time out of 10 times were retained. We then developed the MLR model with the selected variables with the training set, with default settings. Finally, we evaluated the performance of the model with the test set, by both $R^{2}$ and the accuracy of predicting categories (Figure 3).

\section{Estimating the relative importance of variables}

We estimated the relative importance of each variable with the Leave-One-Covariate-Out (LOCO) method as described previously (Lei et al, 2018). Briefly, we removed one variable out at a time from the MLR model, obtained a new $R^{2}$, calculated the decrease in $R^{2}$ as a percentage defined as $\left(R_{\text {full model }}^{2}\right.$ $R^{2}$ reduced model $/ / R_{\text {full model }}^{2}$, and used this metric as the relative importance of the variable. Supplementary Tables S1 and S2 show the results of this evaluation.

\section{Data availability}

All scripts and models were deposited on github (https://github.com/sw5019/Fluvacc-metadata-project).

\section{Acknowledgments}

CV and TR acknowledge funding by the US National Institutes of Health (R35GM127089 and 75N93019C00052/NH/NIH HHS/United States). HC was supported in part by National Medical Research Council, Singapore (NMRC/CG/M009/2017). Cohort data was obtained from a study supported by the National Center for Advancing Translational Sciences of the National Institutes of Health under Award Number UL1TR002378. EG was supported in part by the Division of Intramural Research (DIR) of the NIAID/NIH.

The authors declare that they have no conflict of interest. 


\section{Figures / Tables}

\section{Figure 1. The UGA flu vaccination cohort includes diverse participants with multi-dimensional prior information}

A. Data for flu vaccine cohort by University of Georgia at Athens (UGA) spanning 5 flu seasons. For each of the human participants, day 0 (D0) and day 21/28 (D21/D28) antibody titer levels against each of four vaccine strains were measured using the hemagglutination inhibition assay (HAl). B. Distribution of composite D0 and D28 HAI titer levels in the Children ( $<18$ years old), Adult1 (18-64 years old), and Adult2 (>=65 years old) subpopulations. Similar to the definition of composite seroconversion, composite D0/D28 titer is defined as the sum of $\log _{2}$ (D0 titer level) or (D28 titer level) across 4 vaccine strains. Seropositivity cutoff is the composite titer level when titer is 40 in all 4 strains $\left(4^{*} \log _{2}(40)\right)$. HAI, hemagglutination inhibition assay. C-E. Distribution of composite seroconversion, age, and BMI in 3 subpopulations. F-J. Distribution of categorical variables in 3 subpopulations. For comorbidities variable, yes indicates having $>=1$ of the comorbidities that are surveyed and no indicates having none $(\mathbf{H})$. For vaccine dose, high dose is offered as an option only to Adult2 subpopulation (J). K. Fraction of participants that are vaccinated in each month in a flu season. Sep., September; Oct., October; Nov., November; Dec., December; Jan., January; Feb., February. 
medRxiv preprint doi: https://doi.org/10.1101/2021.10.07.21264416; this version posted October 11, 2021. The copyright holder for this preprint (which was not certified by peer review) is the author/funder, who has granted medRxiv a license to display the preprint in perpetuity.

It is made available under a CC-BY-NC-ND 4.0 International license.

A

UGA1 (2016-2017)

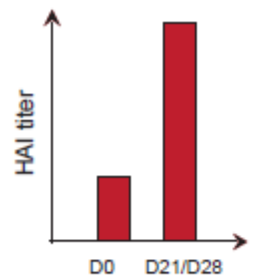

B

Time 追 Do 官 D28

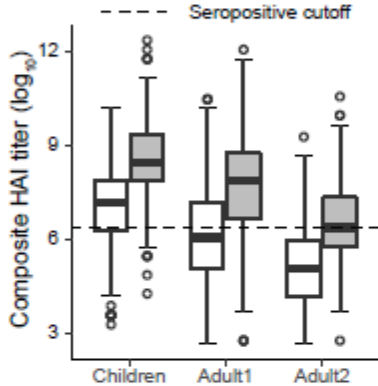

$\mathbf{F}$

$\square$ Male $\square$ Female

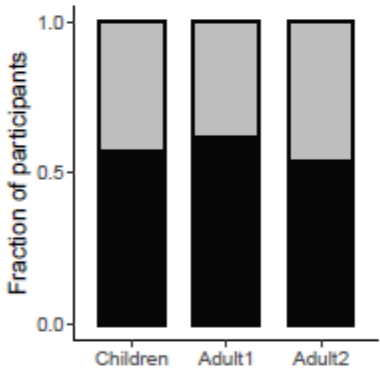

J

Dose $\square$ Standard $\square$ High

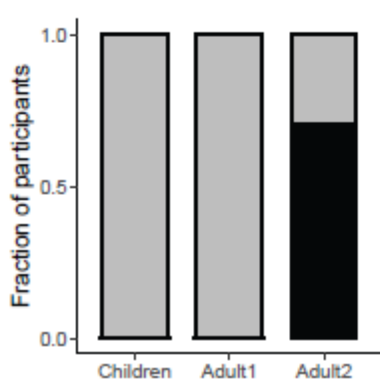

UGA2 (2017-2018)

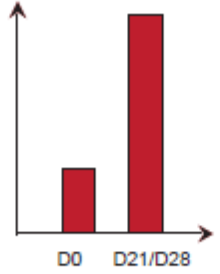

C

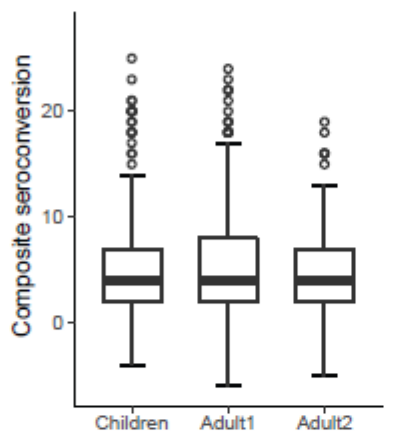

G
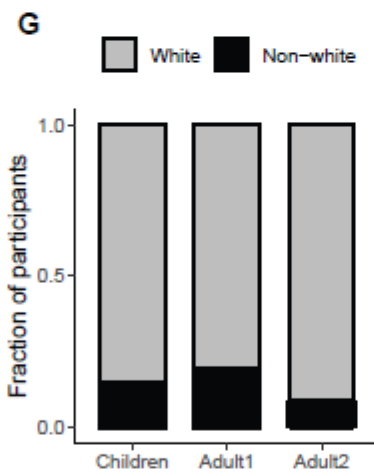

K

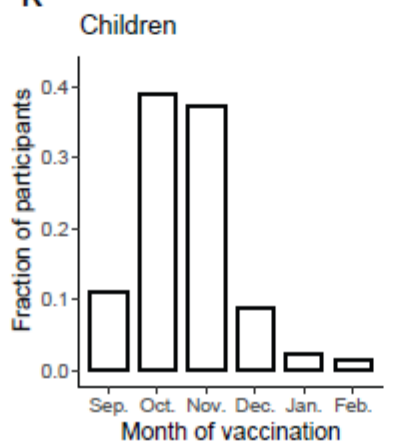

UGA3 (2018-2019)

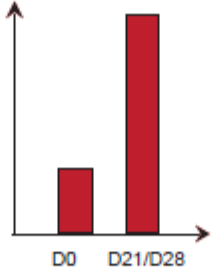

D

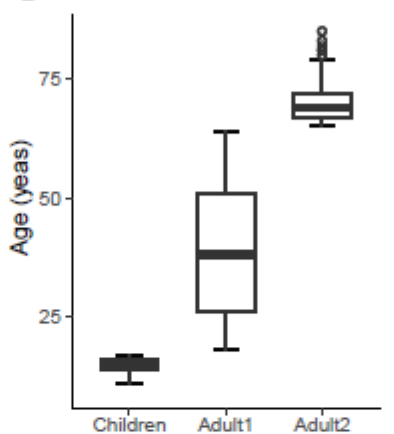

$\mathrm{H}$
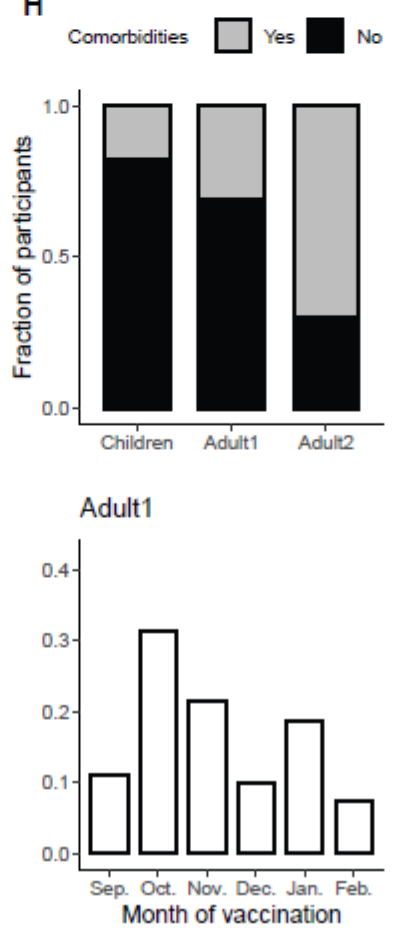

UGA5 (2020-2021)

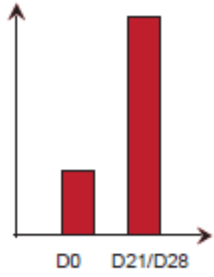

E

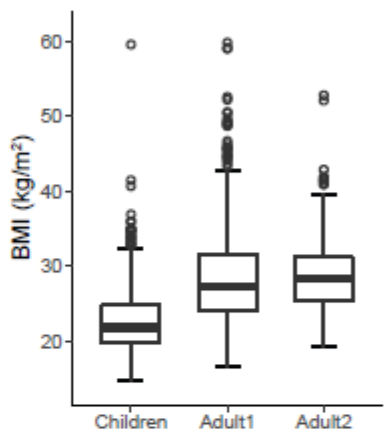

I

$\square$ Naive

Prevaccinated

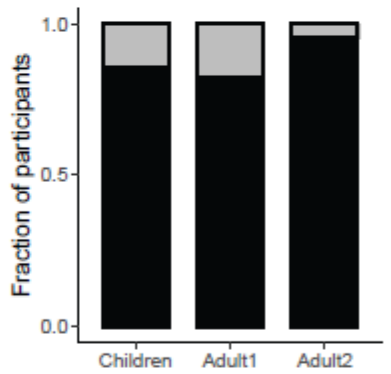

Adult2

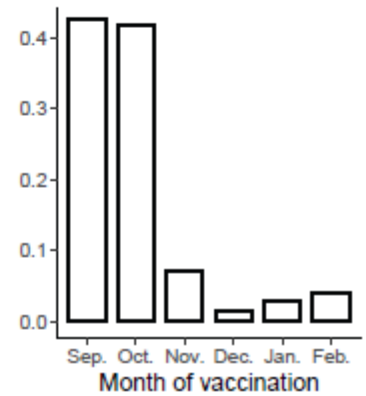


medRxiv preprint doi: https://doi.org/10.1101/2021.10.07.21264416; this version posted October 11, 2021. The copyright holder for this preprint (which was not certified by peer review) is the author/funder, who has granted medRxiv a license to display the preprint in perpetuity.

It is made available under a CC-BY-NC-ND 4.0 International license.

\section{Figure 2. Some priors are intercorrelated}

A. Correlation between prevaccination history and baseline across three subpopulations. $P$ value is calculated from the $T$ test. B. Correlation between age and BMI across three subpopulations. $R$ is calculated from Pearson's correlation.
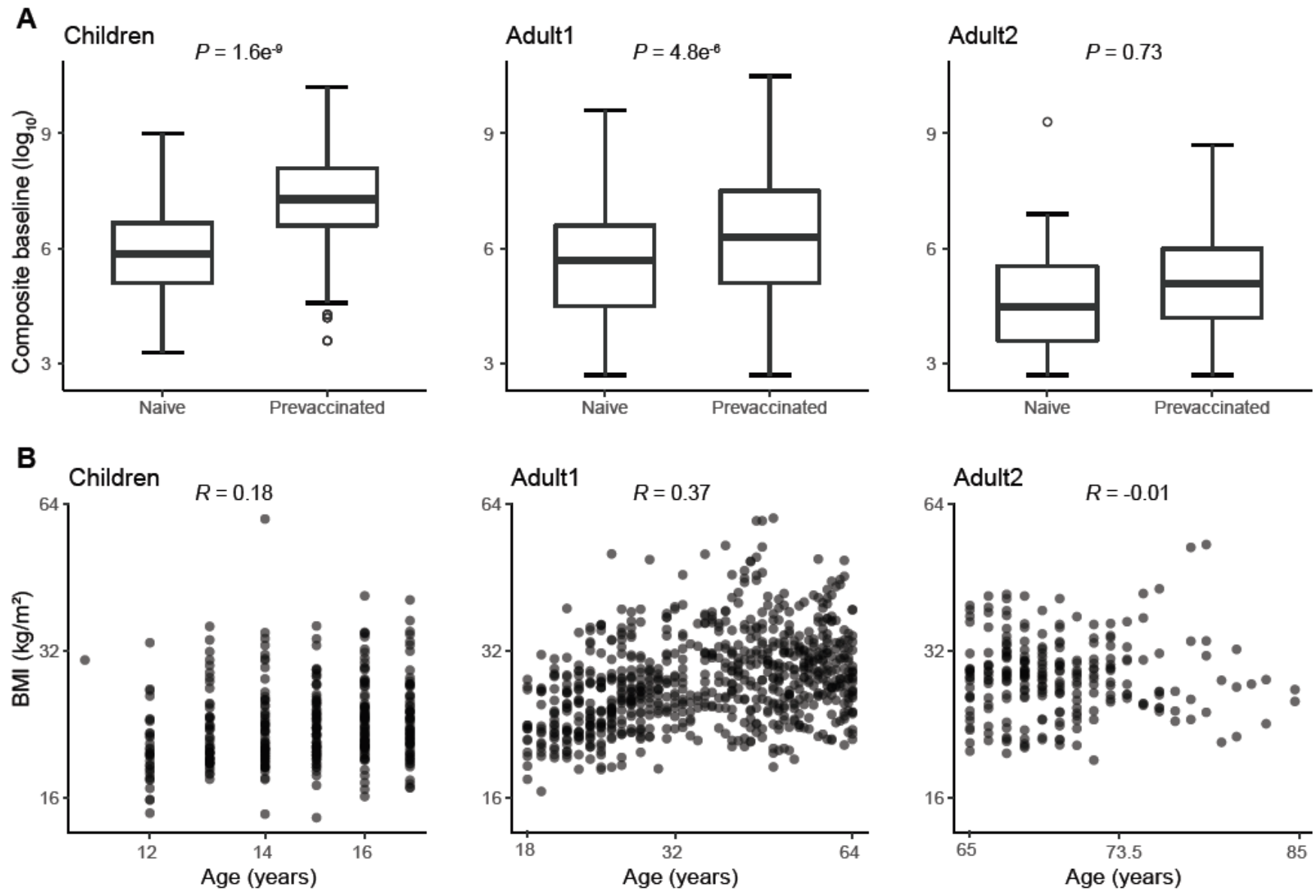
medRxiv preprint doi: https://doi.org/10.1101/2021.10.07.21264416; this version posted October 11, 2021. The copyright holder for this preprint (which was not certified by peer review) is the author/funder, who has granted medRxiv a license to display the preprint in perpetuity. It is made available under a CC-BY-NC-ND 4.0 International license .

\section{Figure 3. A multiple linear regression model aims at removing confounding factors when predicting the response to vaccination}

Variables for Seroconversion prediction and BaselineSY prediction, respectively, in each of the 3 subpopulations, and machine learning strategy used to predict Seroconversion and BaselineSY. MLR, multiple linear regression.

\section{Input}
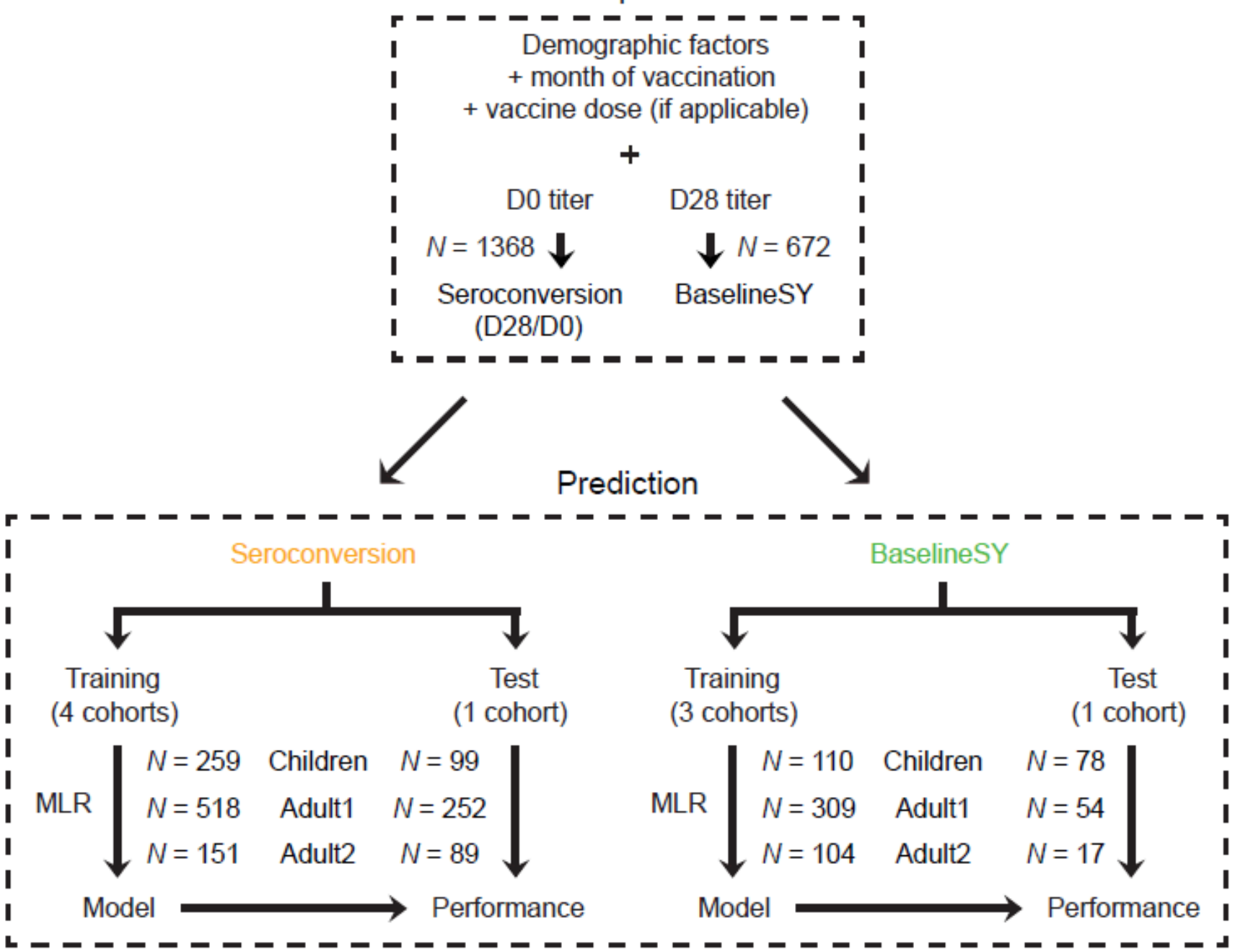
medRxiv preprint doi: https://doi.org/10.1101/2021.10.07.21264416; this version posted October 11, 2021. The copyright holder for this preprint (which was not certified by peer review) is the author/funder, who has granted medRxiv a license to display the preprint in perpetuity.

It is made available under a CC-BY-NC-ND 4.0 International license .

\section{Figure 4. The model predicts seroconversion and long-term titer levels with high accuracy}

A. Observed vs. predicted values for Seroconversion. Predicted values are obtained for the test set only (UGA4, see Figure 1). Dashed lines mark the cutoff for high seroconversion (>=8). White and grey quadrants show areas of correct and incorrect prediction of high and low/no seroconversion, respectively. Percentages listed in blue denote correct predictions. B. Observed vs. predicted values for BaselineSY. Predicted values are obtained for the test set only (repeated participants in cohorts 3-4). Dashed lines mark the cutoff for seropositivity $\left(>=4^{*} \log _{2}(40)\right)$. White and grey quadrants show areas of correct and incorrect prediction of seropositive and seronegative baseline, respectively. Percentages listed in blue denote correct predictions.

A

Children

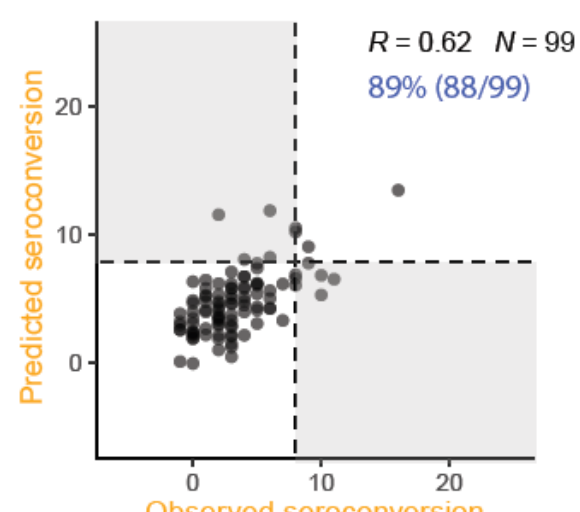

B

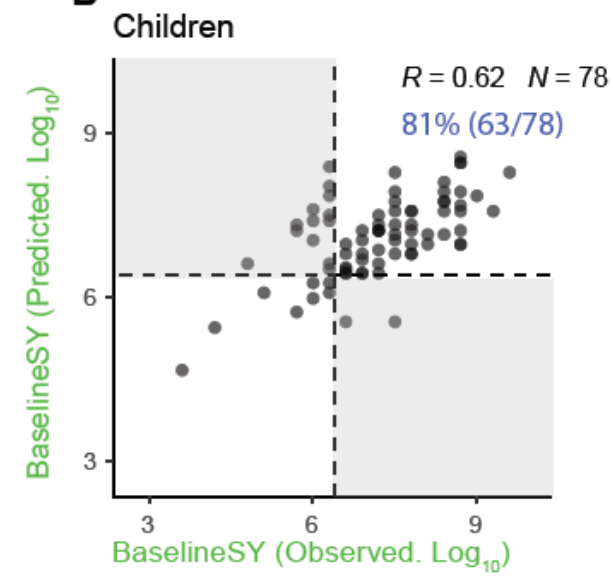

Adult1

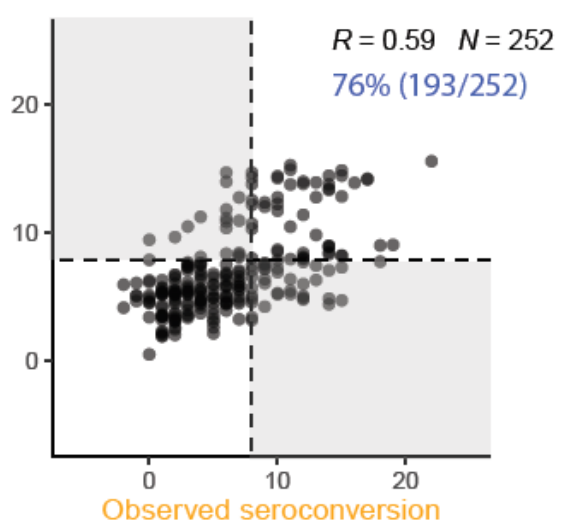

Adult1

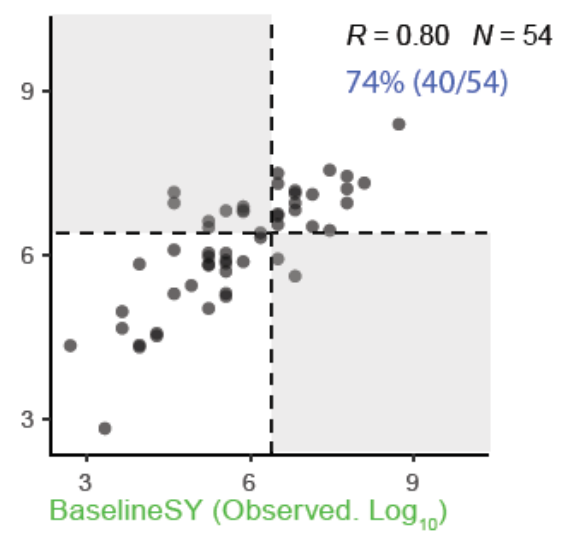

Adult2

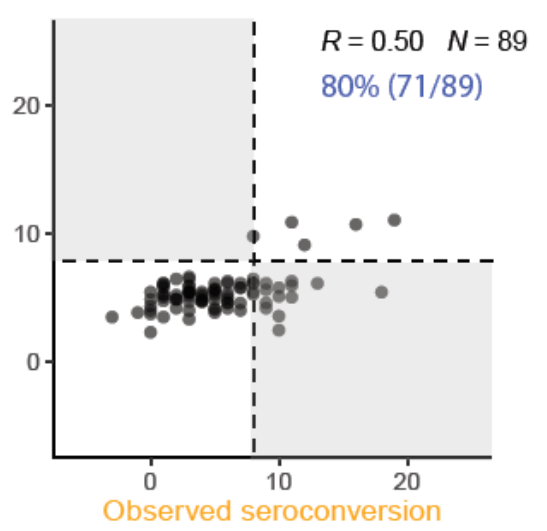

Adult2

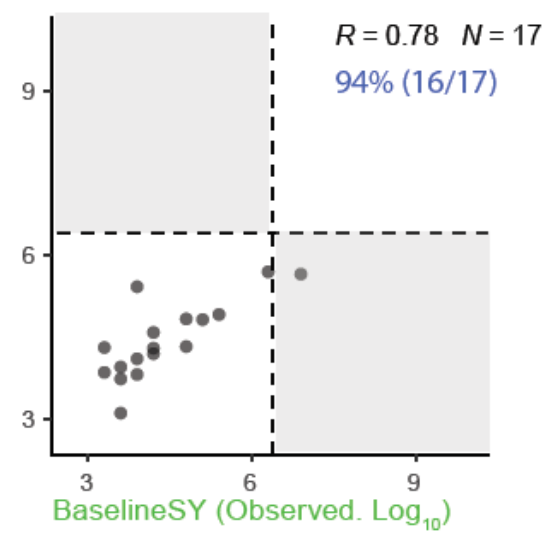


medRxiv preprint doi: https://doi.org/10.1101/2021.10.07.21264416; this version posted October 11, 2021. The copyright holder for this preprint (which was not certified by peer review) is the author/funder, who has granted medRxiv a license to display the preprint in perpetuity.

It is made available under a CC-BY-NC-ND 4.0 International license.

\section{Figure 5. Individual priors have different contributions to response prediction}

Relative importance of each variable for prediction. The intensity of the color in each cell denotes the importance, measured as percentage of drop in prediction accuracy measured as squared correlation $\left(R^{2}\right)$ between observed and predicted values (see Methods). Grey denotes non-selected variables. The color denotes the direction of the correlation between the variable and the predicted value, i.e. red and blue values denote positive and negative correlation, respectively, between the variable and Seroconversion or BaselineSY. For example, prevaccination status predicts both Seroconversion and BaselineSY; prevaccinated participants show lower (blue) Seroconversion (all subpopulations) and higher (red) BaselineSY (Children only). Variables with importance $=<3 \%$ or with a coefficient $=<0.1$ in absolute value are labeled in white. HAI, hemagglutination inhibition assay; vacc., vaccination.
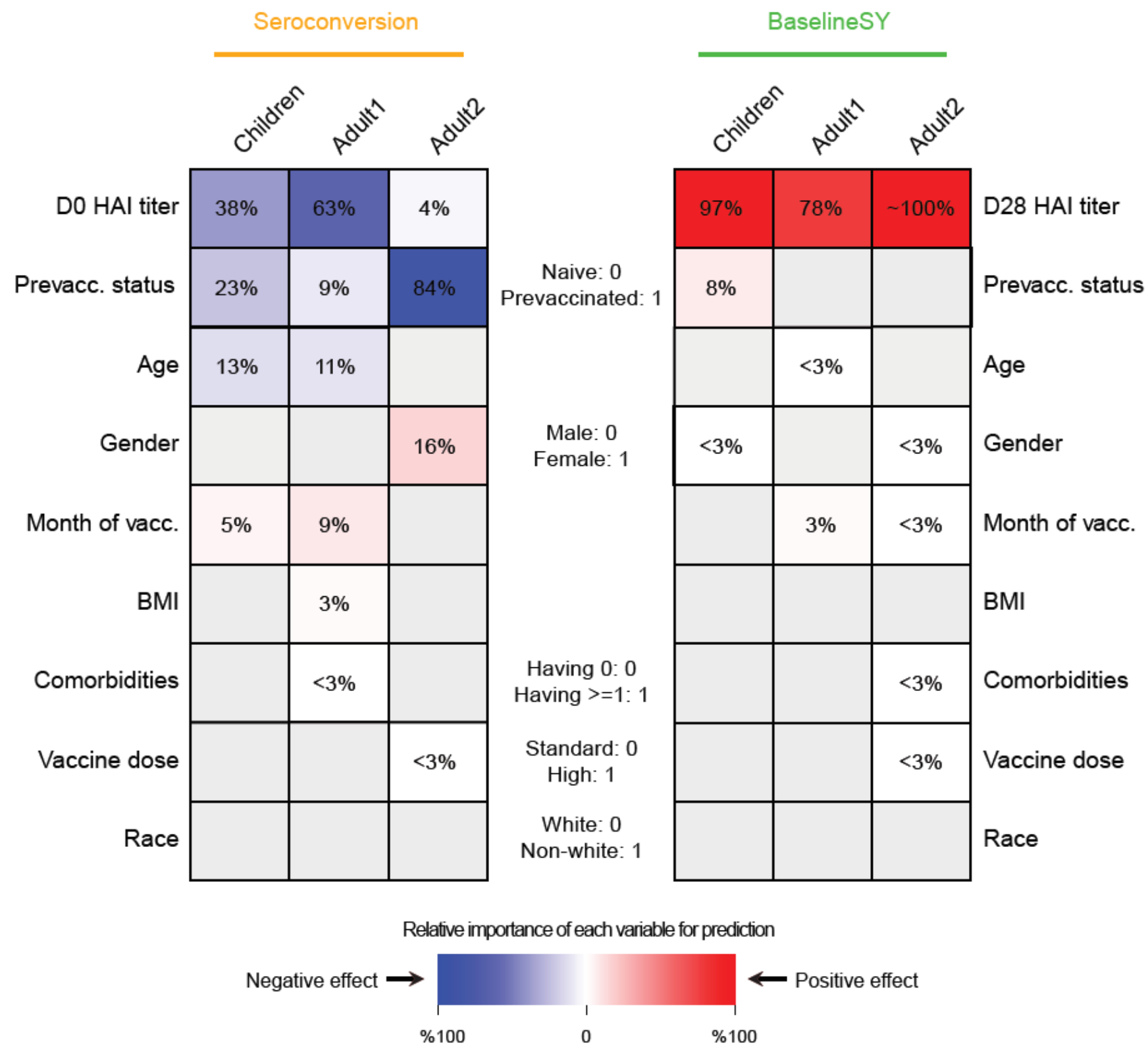
medRxiv preprint doi: https://doi.org/10.1101/2021.10.07.21264416; this version posted October 11, 2021. The copyright holder for this preprint (which was not certified by peer review) is the author/funder, who has granted medRxiv a license to display the preprint in perpetuity.

It is made available under a CC-BY-NC-ND 4.0 International license .

\section{Figure 6. Strain-specific modelling reveals some detailed effects}

Relative importance of each variable for prediction. The intensity of the color in each cell denotes the importance, measured as percentage of drop in prediction accuracy measured as squared correlation $\left(R^{2}\right)$ between observed and predicted values (see Methods). Grey denotes non-selected significant variables. The color denotes the direction of the correlation between the variable and the predicted value, i.e. red and blue values denote positive and negative correlation, respectively, between the variable and Seroconversion or BaselineSY. Variables with importance $=<3 \%$ or with a coefficient $=<0.1$ in absolute value are labeled in white. IBV, Influenza B Virus; HAI, influenza hemagglutination inhibition assay; vacc., vaccination; Vic, Victoria; Yam, Yamagata. * IBV Yamagata strain is absent in the vaccine in UGA cohorts 1-4, but present in cohort 5.

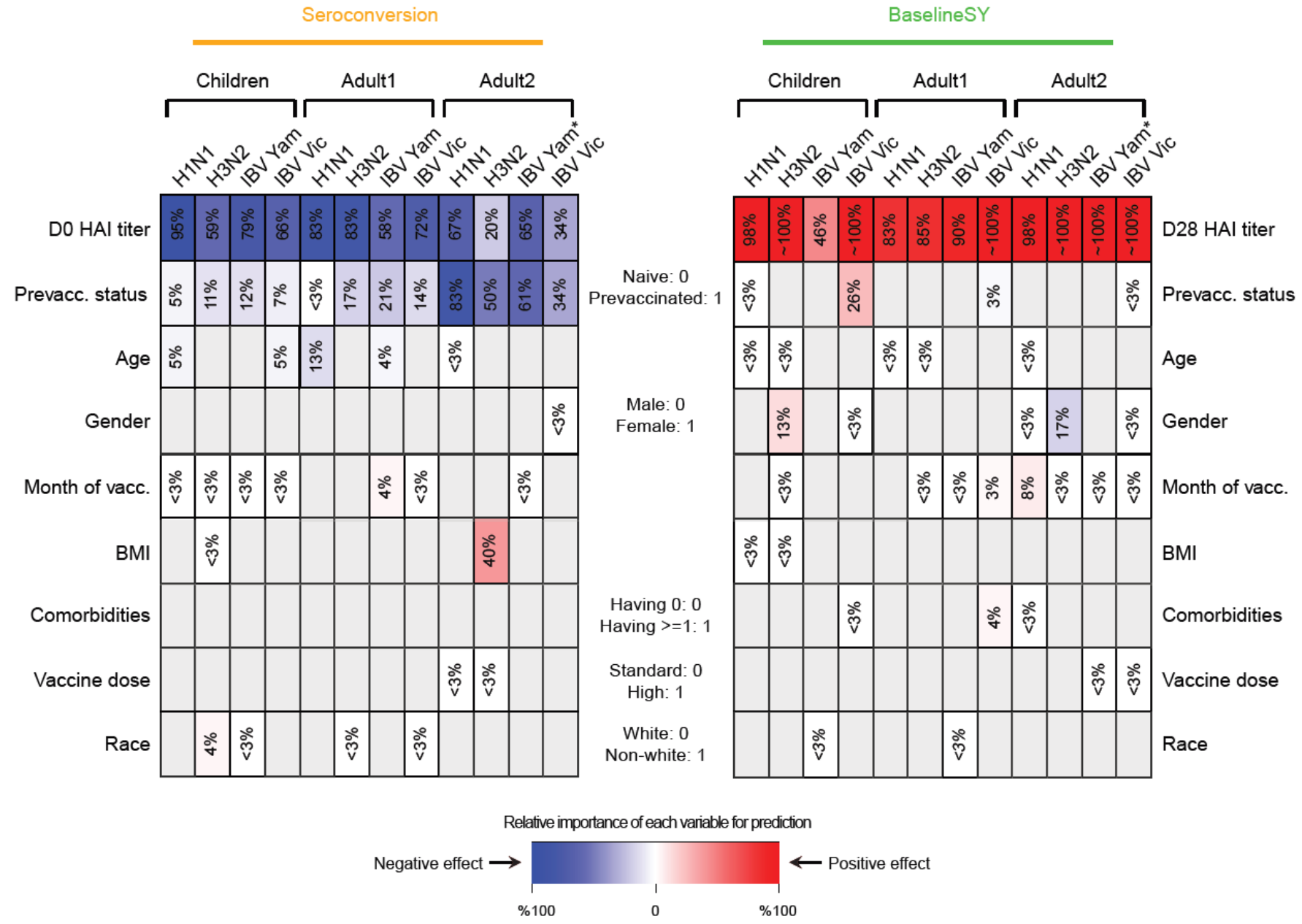


medRxiv preprint doi: https://doi.org/10.1101/2021.10.07.21264416; this version posted October 11, 2021. The copyright holder for this preprint (which was not certified by peer review) is the author/funder, who has granted medRxiv a license to display the preprint in perpetuity.

It is made available under a CC-BY-NC-ND 4.0 International license .

\section{Figure 7. Relationships between age, BMI, and vaccination month, and the} response to vaccination

Partial residual plots illustrating the relationship between a variable ( $\mathrm{x}$-axis) and the target value after removing the impact of all other variables (partial residual, y-axis). Target values are either Seroconversion (A-C) or BaselineSY (D). Vacc., vaccination. We grouped X-axes variables in A-B into 6 equally spaced bins, and showed the median for bin for better illustration, but we calculated $R$ in all panels using the raw data.

A

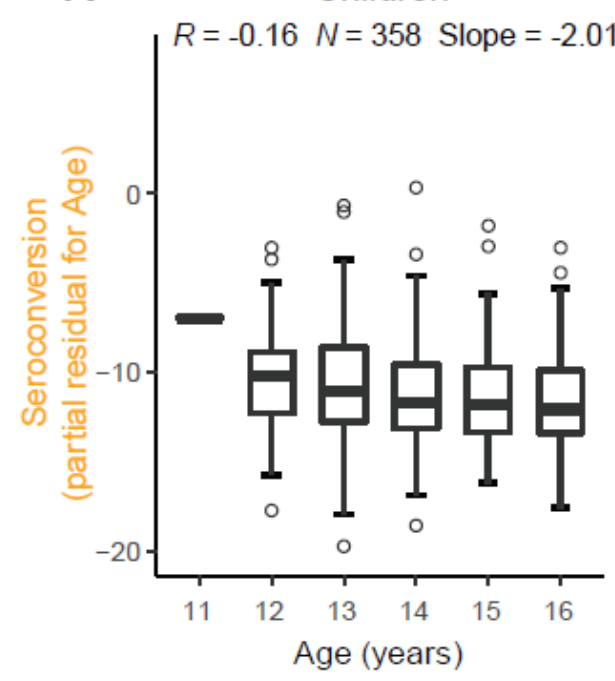

C

Children

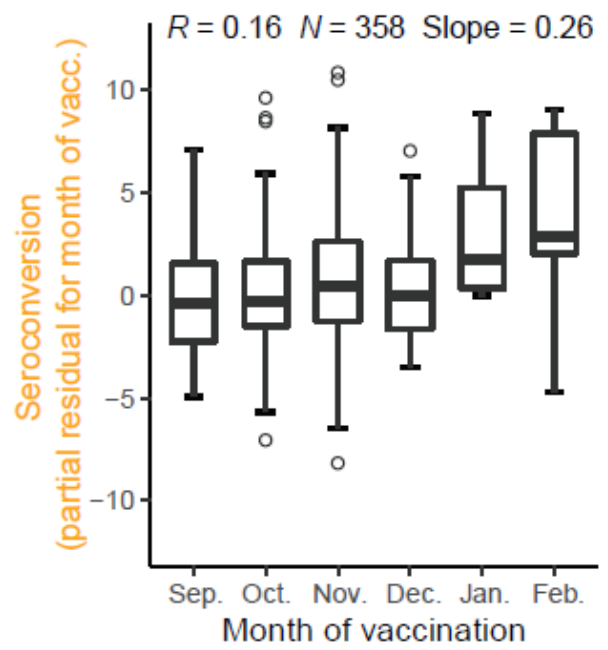

Adult1

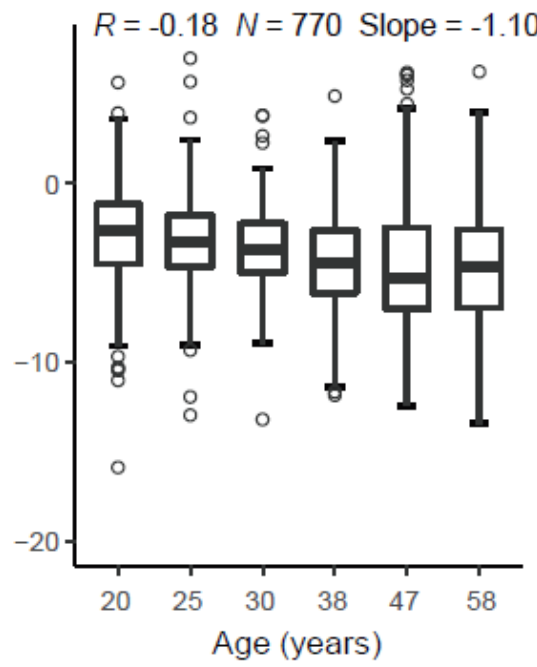

Adult1

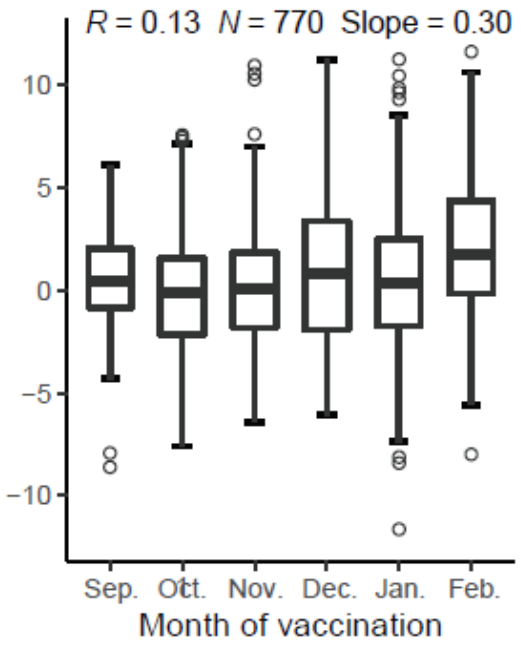

B

Adult1

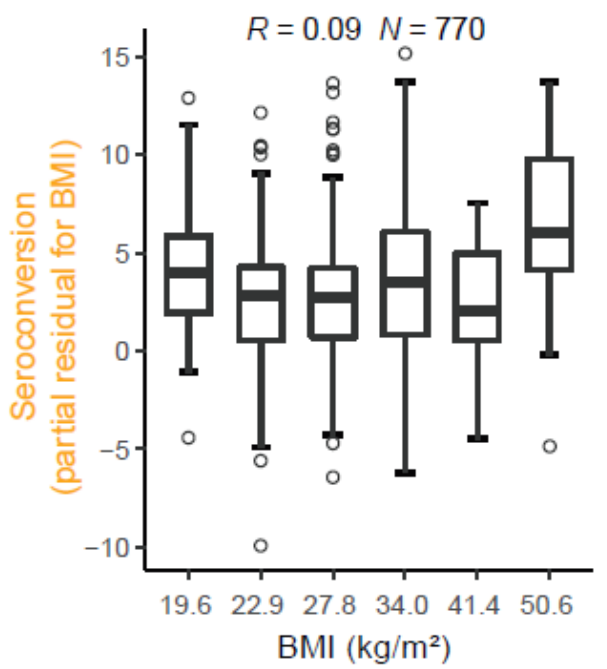

D

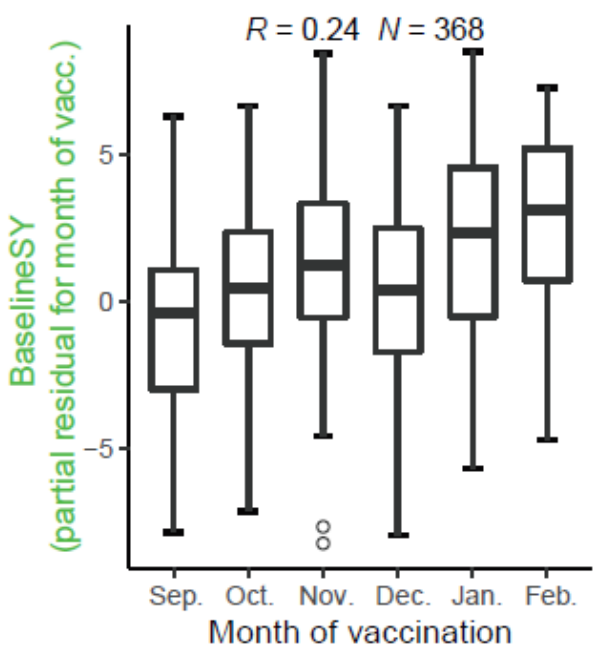


medRxiv preprint doi: https://doi.org/10.1101/2021.10.07.21264416; this version posted October 11, 2021. The copyright holder for this preprint (which was not certified by peer review) is the author/funder, who has granted medRxiv a license to display the preprint in perpetuity. It is made available under a CC-BY-NC-ND 4.0 International license .

\section{Supplementary Notes}

\section{Figure S1. Impact of prevaccination history on seroconversion}

Left panel: among all participants $(N=1,461)$; Right panel: among participants with a low baseline (seropositive strains $=<2 . N=726$ ).
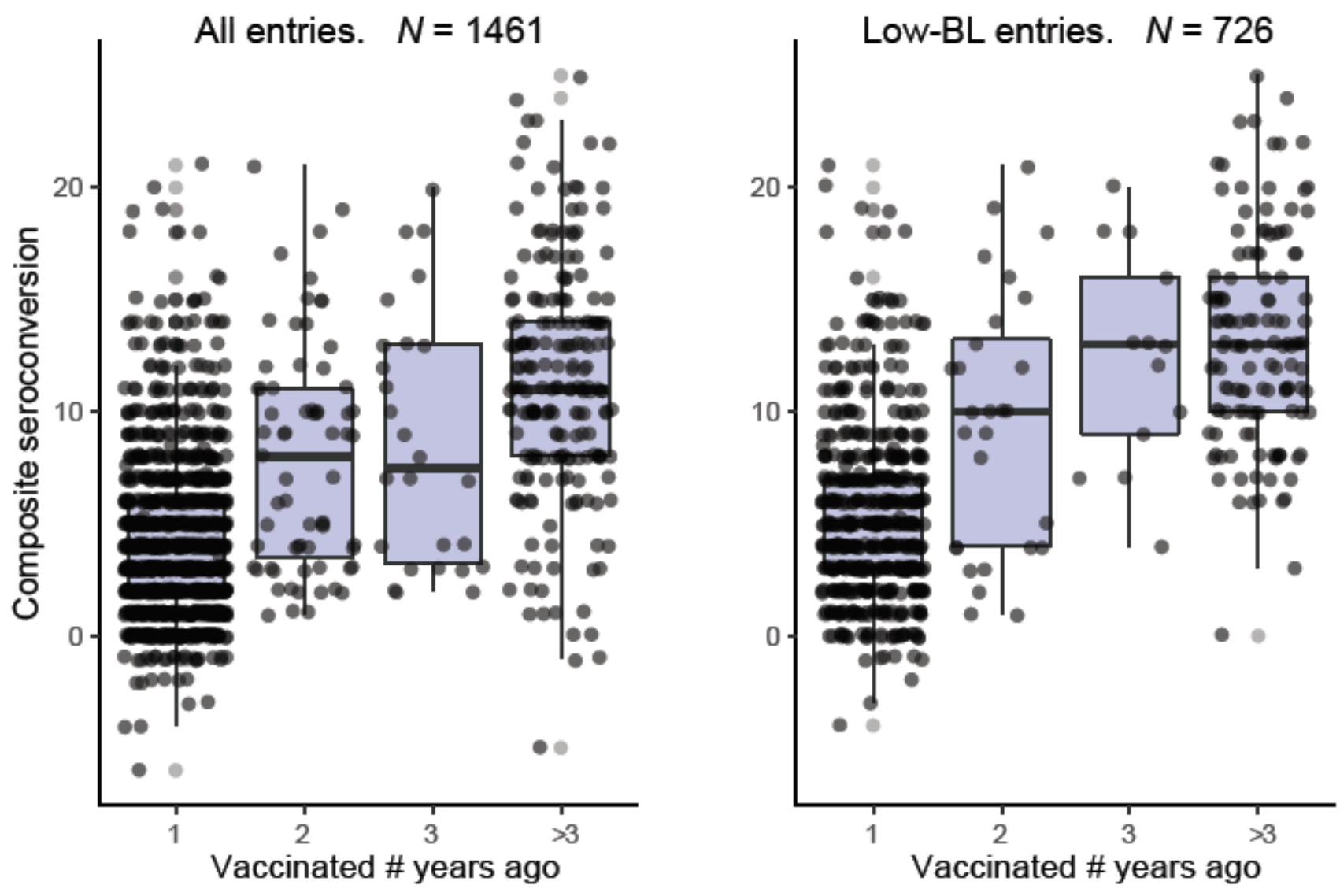
medRxiv preprint doi: https://doi.org/10.1101/2021.10.07.21264416; this version posted October 11, 2021. The copyright holder for this preprint (which was not certified by peer review) is the author/funder, who has granted medRxiv a license to display the preprint in perpetuity. It is made available under a CC-BY-NC-ND 4.0 International license .

\section{Figure S2. Intercorrelations between all variables.}

Intercorrelations between all variables that are included in the modeling. Age and BMI are log2-transformed, and the categorical variables are transformed into numeric values first, then Pearson's correlation is calculated between the variables. *, $\mathrm{P}<0.05 ; * *, \mathrm{P}<0.01 ; * * *, \mathrm{P}<0.001$. Plots along the diagonal are distributions of the variables. The red lines in the correlation plots below the diagonal are loess regression lines. Cmbdts: comorbidities; Prevacc: prevaccination; Vacc: vaccination; BL: baseline - here composite baseline.

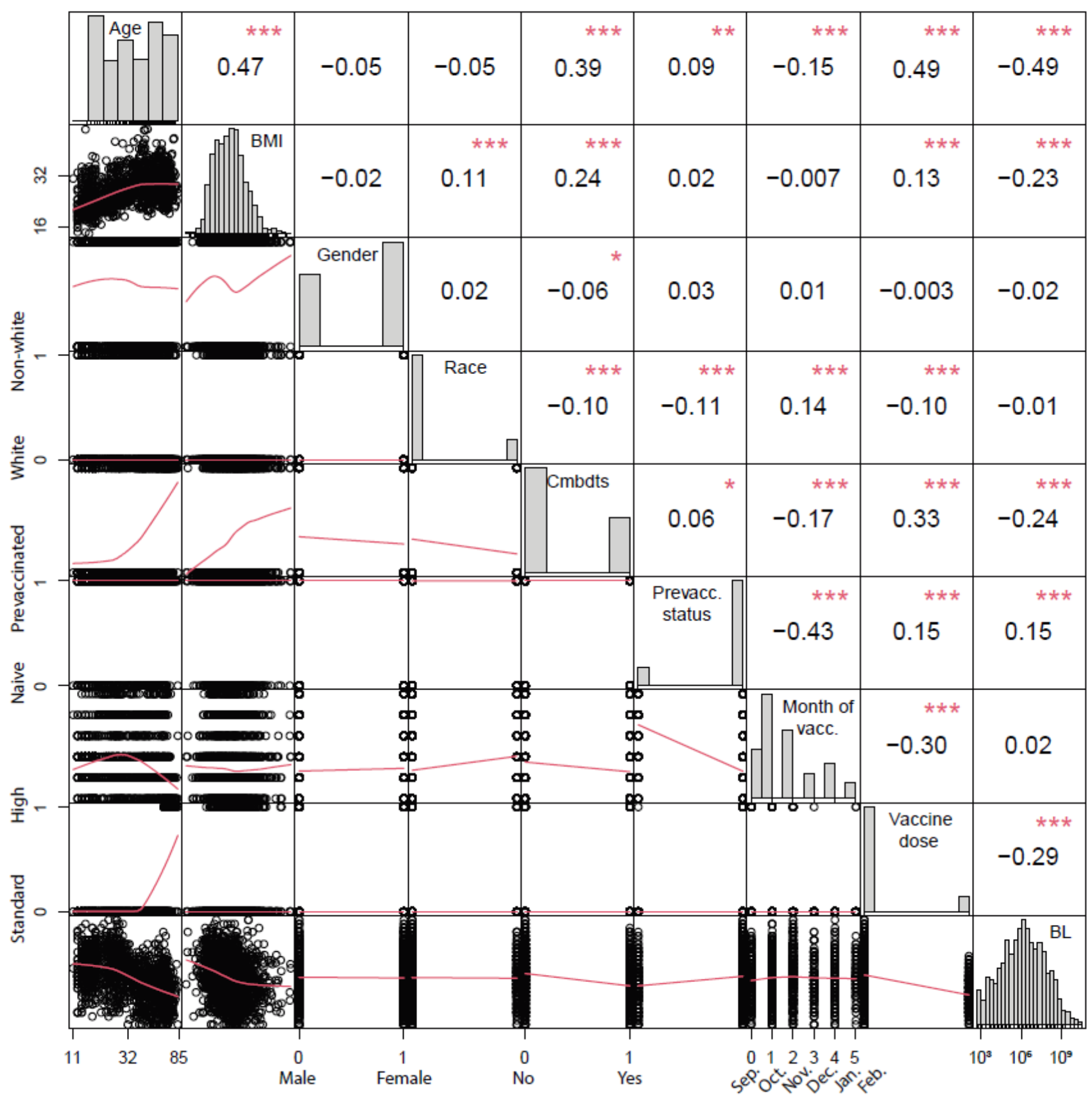


medRxiv preprint doi: https://doi.org/10.1101/2021.10.07.21264416; this version posted October 11, 2021. The copyright holder for this preprint (which was not certified by peer review) is the author/funder, who has granted medRxiv a license to display the preprint in perpetuity.

It is made available under a CC-BY-NC-ND 4.0 International license .

\section{Figure S3. Observed vs. predicted values for Seroconversion and BaselineSY, respectively}

Similar to Figure 4, only that all data points are plotted here.

A

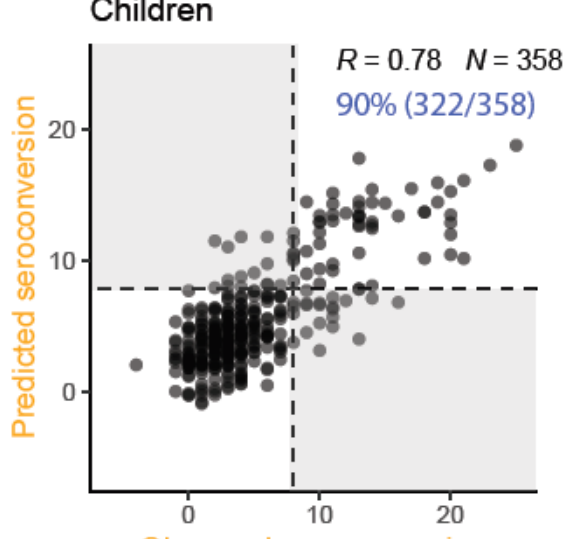

B

Children

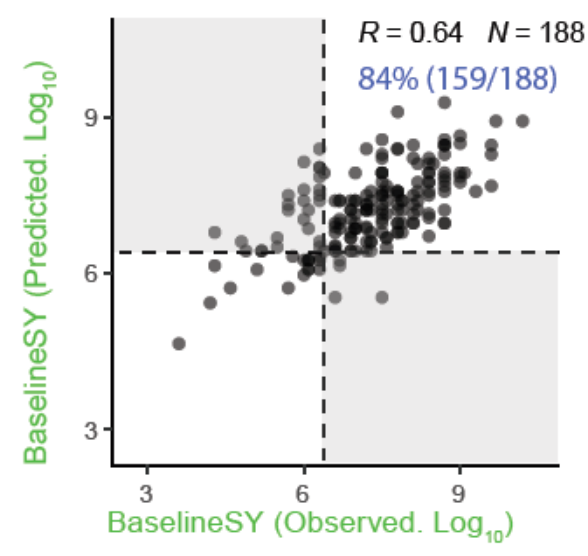

Adult1

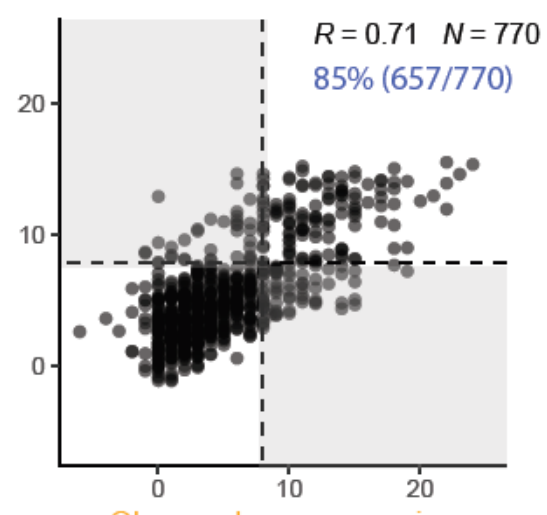

Observed seroconversion

Adult1

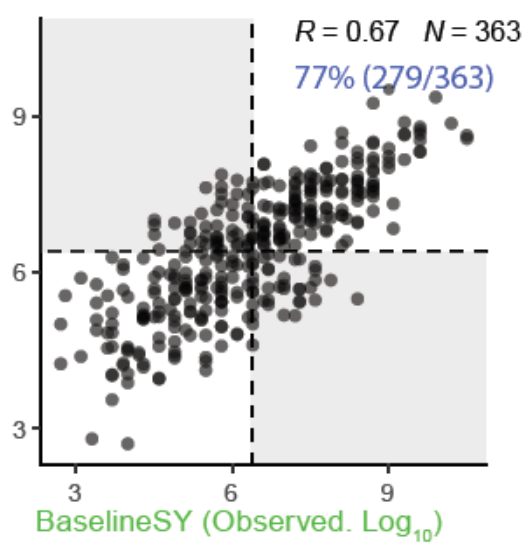

Adult2

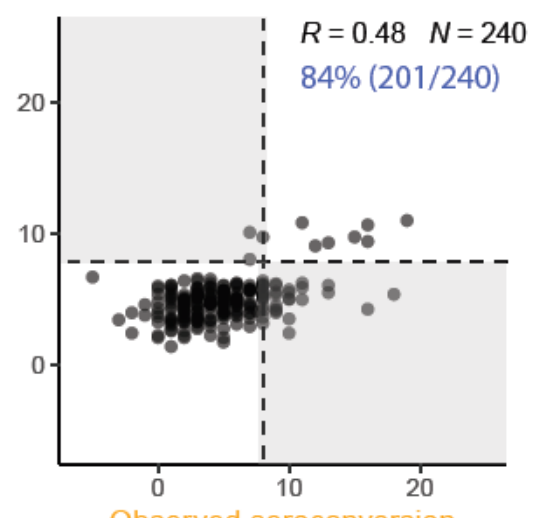

Observed seroconversion

Adult2

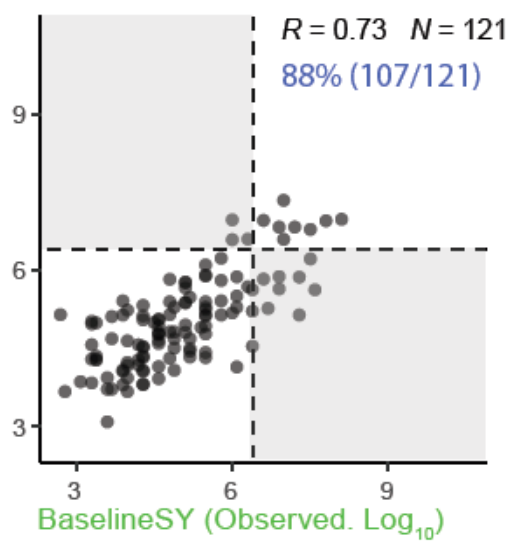


medRxiv preprint doi: https://doi.org/10.1101/2021.10.07.21264416; this version posted October 11, 2021. The copyright holder for this preprint (which was not certified by peer review) is the author/funder, who has granted medRxiv a license to display the preprint in perpetuity. It is made available under a CC-BY-NC-ND 4.0 International license .

Table S1. Relative importance and coefficients of variables for Seroconversion and BaselineSY prediction, respectively - original data.

Excel file.

Table S2. Relative importance and coefficients of variables for Seroconversion and BaselineSY prediction, respectively, for individual strains - original data.

Excel file. 
medRxiv preprint doi: https://doi.org/10.1101/2021.10.07.21264416; this version posted October 11, 2021. The copyright holder for this preprint (which was not certified by peer review) is the author/funder, who has granted medRxiv a license to display the preprint in perpetuity. It is made available under a CC-BY-NC-ND 4.0 International license .

\section{References}

Abreu RB, Kirchenbaum GA, Clutter EF, Sautto GA \& Ross TM (2020) Preexisting subtype immunodominance shapes memory B cell recall response to influenza vaccination. JCI Insight 5 doi:10.1172/jci.insight.132155 [PREPRINT]

Beyer WEP, Palache AM, Sprenger MJW, Hendriksen E, Tukker JJ, Darioli R, van der Water GL, Masurel N \& Osterhaus ADM (1996) Effects of repeated annual influenza vaccination on vaccine sero-response in young and elderly adults. Vaccine 14: 1331-1339 doi:10.1016/s0264-410x(96)00058-8 [PREPRINT]

Borges LGDA, Giongo A, Pereira L de M, Trindade FJ, Gregianini TS, Campos FS, Ghedin E \& da Veiga ABG (2018) Comparison of the nasopharynx microbiome between influenza and non-influenza cases of severe acute respiratory infections: A pilot study. Health Sci Rep 1: e47

Boyd SD \& Jackson KJL (2015) Predicting vaccine responsiveness. Cell Host Microbe 17: 301-307

Brodin P, Jojic V, Gao T, Bhattacharya S, Angel CJL, Furman D, Shen-Orr S, Dekker CL, Swan GE, Butte AJ, et al (2015) Variation in the human immune system is largely driven by non-heritable influences. Cell 160: $37-47$

Callahan ST, Wolff M, Hill HR, Edwards KM \& NIAID Vaccine and Treatment Evaluation Unit (VTEU) Pandemic H1N1 Vaccine Study Group (2014) Impact of body mass index on immunogenicity of pandemic H1N1 vaccine in children and adults. J Infect Dis 210: 1270-1274

DiazGranados CA, Dunning AJ, Jordanov E, Landolfi V, Denis M \& Keipp Talbot H (2013) High-dose trivalent influenza vaccine compared to standard dose vaccine in elderly adults: Safety, immunogenicity and relative efficacy during the 2009-2010 season. Vaccine 31: 861-866 doi:10.1016/j.vaccine.2012.12.013 [PREPRINT]

Fink AL, Engle K, Ursin RL, Tang W-Y \& Klein SL (2018) Biological sex affects vaccine efficacy and protection against influenza in mice. Proc Natl Acad Sci U S A 115: 12477-12482

Franco LM, Bucasas KL, Wells JM, Niño D, Wang X, Zapata GE, Arden N, Renwick A, Yu P, Quarles JM, et al (2013) Integrative genomic analysis of the human immune response to influenza vaccination. Elife 2: e00299

Frasca D, Ferracci F, Diaz A, Romero M, Lechner S \& Blomberg BB (2016) Obesity decreases B cell responses in young and elderly individuals. Obesity 24: 615-625 doi:10.1002/oby.21383 [PREPRINT]

Ghedin E \& Schultz-Cherry S (2017) Host response: Pregnancy impairs flu defences. Nat Microbiol 2: 17077

Gonzalez-Dias P, Lee EK, Sorgi S, de Lima DS, Urbanski AH, Silveira EL \& Nakaya HI (2020) Methods for predicting vaccine immunogenicity and reactogenicity. Hum Vaccin Immunother 16: 269-276

Goodwin K, Viboud C \& Simonsen L (2006) Antibody response to influenza vaccination in the elderly: a quantitative review. Vaccine 24: 1159-1169

Gouma S, Zost SJ, Parkhouse K, Branche A, Topham DJ, Cobey S \& Hensley SE (2020) Comparison of Human H3N2 Antibody Responses Elicited by Egg-Based, Cell-Based, and Recombinant Protein-Based Influenza Vaccines During the 2017-2018 Season. Clin Infect Dis 71: 1447-1453 
medRxiv preprint doi: https://doi.org/10.1101/2021.10.07.21264416; this version posted October 11, 2021. The copyright holder for this preprint (which was not certified by peer review) is the author/funder, who has granted medRxiv a license to display the preprint in perpetuity. It is made available under a CC-BY-NC-ND 4.0 International license .

Gounder AP \& Boon ACM (2019) Influenza Pathogenesis: The Effect of Host Factors on Severity of Disease. The Journal of Immunology 202: 341-350 doi:10.4049/jimmunol.1801010 [PREPRINT]

Henn AD, Wu S, Qiu X, Ruda M, Stover M, Yang H, Liu Z, Welle SL, Holden-Wiltse J, Wu H, et al (2013) High-resolution temporal response patterns to influenza vaccine reveal a distinct human plasma cell gene signature. Sci Rep 3: 2327

Henry C, Zheng N-Y, Huang M, Cabanov A, Rojas KT, Kaur K, Andrews SF, Palm A-KE, Chen Y-Q, Li Y, et al (2019) Influenza Virus Vaccination Elicits Poorly Adapted B Cell Responses in Elderly Individuals. Cell Host Microbe 25: 357-366.e6

HIPC-CHI Signatures Project Team \& HIPC-I Consortium (2017) Multicohort analysis reveals baseline transcriptional predictors of influenza vaccination responses. Sci Immunol 2

Honce R, Karlsson EA, Wohlgemuth N, Estrada LD, Meliopoulos VA, Yao J \& Schultz-Cherry S (2020) Obesity-Related Microenvironment Promotes Emergence of Virulent Influenza Virus Strains. MBio 11

Honce R \& Schultz-Cherry S (2019) Impact of Obesity on Influenza A Virus Pathogenesis, Immune Response, and Evolution. Front Immunol 10: 1071

Huang QS, Bandaranayake D, Wood T, Newbern EC, Seeds R, Ralston J, Waite B, Bissielo A, Prasad N, Todd A, et al (2019) Risk Factors and Attack Rates of Seasonal Influenza Infection: Results of the Southern Hemisphere Influenza and Vaccine Effectiveness Research and Surveillance (SHIVERS) Seroepidemiologic Cohort Study. J Infect Dis 219: 347-357

Ivanciuc O (2008) Weka machine learning for predicting the phospholipidosis inducing potential. Curr Top Med Chem 8: 1691-1709

Kenney AD, Dowdle JA, Bozzacco L, McMichael TM, St Gelais C, Panfil AR, Sun Y, Schlesinger LS, Anderson MZ, Green PL, et al (2017) Human Genetic Determinants of Viral Diseases. Annu Rev Genet 51: $241-263$

Klein SL \& Flanagan KL (2016) Sex differences in immune responses. Nature Reviews Immunology 16: 626-638 doi:10.1038/nri.2016.90 [PREPRINT]

Kotliarov Y, Sparks R, Martins AJ, Mulè MP, Lu Y, Goswami M, Kardava L, Banchereau R, Pascual V, Biancotto A, et al (2020) Broad immune activation underlies shared set point signatures for vaccine responsiveness in healthy individuals and disease activity in patients with lupus. Nat Med 26: 618-629

Lei J, G'Sell M, Rinaldo A, Tibshirani RJ \& Wasserman L (2018) Distribution-Free Predictive Inference for Regression. Journal of the American Statistical Association 113: 1094-1111 doi:10.1080/01621459.2017.1307116 [PREPRINT]

Nuttall FQ (2015) Body Mass Index. Nutrition Today 50: 117-128 doi:10.1097/nt.0000000000000092 [PREPRINT]

Orrù V, Steri M, Sole G, Sidore C, Virdis F, Dei M, Lai S, Zoledziewska M, Busonero F, Mulas A, et al (2013) Genetic variants regulating immune cell levels in health and disease. Cell 155: 242-256

Penkert RR, Patel N, Webby RJ, Ross TM \& Hurwitz JL (2021) Month of Influenza Virus Vaccination Influences Antibody Responses in Children and Adults. Vaccines (Basel) 9

Sheridan PA, Paich HA, Handy J, Karlsson EA, Hudgens MG, Sammon AB, Holland LA, Weir S, Noah TL \& Beck MA (2012) Obesity is associated with impaired immune response to influenza vaccination in humans. Int J Obes 36: 1072-1077 
medRxiv preprint doi: https://doi.org/10.1101/2021.10.07.21264416; this version posted October 11, 2021. The copyright holder for this preprint (which was not certified by peer review) is the author/funder, who has granted medRxiv a license to display the preprint in perpetuity.

It is made available under a CC-BY-NC-ND 4.0 International license .

Sung M-H, Shen Y, Handel A, Bahl J \& Ross TM (2021) Longitudinal Assessment of Immune Responses to Repeated Annual Influenza Vaccination in a Human Cohort of Adults and Teenagers. Frontiers in Immunology 12 doi:10.3389/fimmu.2021.642791 [PREPRINT]

Talbot HK, Coleman LA, Crimin K, Zhu Y, Rock MT, Meece J, Shay DK, Belongia EA \& Griffin MR (2012) Association between obesity and vulnerability and serologic response to influenza vaccination in older adults. Vaccine 30: 3937-3943

Tsang JS, Dobaño C, VanDamme P, Moncunill G, Marchant A, Othman RB, Sadarangani M, Koff WC \& Kollmann TR (2020) Improving Vaccine-Induced Immunity: Can Baseline Predict Outcome? Trends Immunol 41: 457-465

Voigt EA, Ovsyannikova IG, Kennedy RB, Grill DE, Goergen KM, Schaid DJ \& Poland GA (2019) Sex Differences in Older Adults' Immune Responses to Seasonal Influenza Vaccination. Front Immunol 10: 180

Voth DW, Feldman HA \& Steinschneider A (1966) Comparative responses of elderly persons to aqueous and depot influenza vaccines. Arch Environ Health 13: 576-585

Zimmermann MT, Oberg AL, Grill DE, Ovsyannikova IG, Haralambieva IH, Kennedy RB \& Poland GA (2016) System-Wide Associations between DNA-Methylation, Gene Expression, and Humoral Immune Response to Influenza Vaccination. PLoS One 11: e0152034

Zost SJ, Parkhouse K, Gumina ME, Kim K, Diaz Perez S, Wilson PC, Treanor JJ, Sant AJ, Cobey S \& Hensley SE (2017) Contemporary H3N2 influenza viruses have a glycosylation site that alters binding of antibodies elicited by egg-adapted vaccine strains. Proc Natl Acad Sci U S A 114: 12578-12583 